\title{
Notes on the Terminology for Print in Early Sanskrit Printed Books
}

\begin{abstract}
The present article deals with liminal material belonging to both the realm of manuscript as well as print culture. Early Sanskrit printed books provide scarce and ambiguous bibliographical information. The Sanskrit terminology used in their imprints is often obscure at best, if not unintelligible without having previous knowledge of the roles of the persons involved in the printing process. Conversely, a correct understanding of the Sanskrit terminology for print is necessary to assess the roles of the people involved in the printing activity. This article examines the Sanskrit terminology for print occurring in the earliest Sanskrit incunabula and lithographs, in order to shed some light on the publication process of early Sanskrit prints.
\end{abstract}

\section{Introduction}

Terminology for print in early Sanskrit printed books is seemingly a trivial subject, but in reality it might prove to be an important tool in the reconstruction of the cultural, social, and technological history of nineteenth-century South Asia. As is well known, in South Asia the production of manuscripts continued to thrive well into the twentieth century, alongside the diffusion of print. Printing presses were already known in South India in the second half of the sixteenth century, however the first Sanskrit book was printed in Kolkata in 1792. The diffusion of typography in nineteenth-century India is paralleled by the widespread diffusion of lithography as a means of reproduction of texts in a large number of scripts. So far little attention has been devoted, for instance, to Sanskrit lithographic material as compared to lithographed books in vernacular languages. Yet, as I will try to demonstrate, intriguing questions arise when we devote our attention to this type of material. Were the scribes active in the production of manuscripts for the manuscript market and readership different from the scribes who worked for lithographic printing presses or were they the same persons? Were the roles of those involved in these printing presses always neatly distinguishable or did they sometime overlap and for instance scribe, editor, and printer were one and the same? Where is the information provided in manuscript colophons found in lithographed and typographed books? Is it provided 
in the same form or not, and why? The answers to these and other questions can be found only if we set out to fulfil the tedious task of reading the primary sources, i.e. the title pages, colophons, and other paratexts of early Sanskrit prints from South Asia'.

After this short introduction, I provide the description of the primary sources analysed. In the third section I discuss the terminology for print as exemplified in the selected Sanskrit lithographs and incunabula described in the previous section, comparing it to the terminology found in colophons of South Asian manuscripts from different periods and areas. Finally, the fourth part of the article is devoted to some preliminary thoughts and conclusions based on the material examined.

\section{Primary Sources}

The material is presented here in chronological order starting with typography, the first printing technique introduced in South Asia by the colonial powers in the sixteenth century. Each entry consists of four parts: a short bibliographical note, the Sanskrit text, its English translation, and if needed, a short commentary. In the latter, only specific points related to the Sanskrit text or the English translation are dealt with, while more general issues related to print terminology and culture are discussed in $\S 3$. The selection of volumes presented here is necessarily limited due to space constraints and access to the material itself. The worldwide situation caused by the pandemic greatly limited access to primary sources, forcing me to limit the selection to material I had already examined or that is available in the Bodleian Libraries. It is for this reason that some bibliographical information is less detailed than other, since I was able to consult some books only in electronic format. I beg the readers for forgiveness.

1 The material considered in the present study corresponds to the following definition of Sanskrit print: 'any print containing a complete Sanskrit work, regardless of other features (such as the presence of a translation in another language), and printed in South Asia' (Formigatti 2016, 76). 


\title{
2.1 Incunabula
}

\subsubsection{Nāmalingānuśāsana, Trikaṇḍaśeṣa, Hārāvalī, Nānārthaśabdakośa}

Bodleian Libraries, Oxford: Sansk. 4.160 (Bābūrāma 1807b).

Published in Kolkata at the Sanskrit Press in 1807. Format: codex.

\author{
[Title page] \\ śrīmadamarakṛtakoṣaḥ (!) puruṣottamakṛtatrikaṇdaśeșañ ca| \\ hārāvalyabhidhānam medinīkarasya nānārthaḥ || 1 || \\ nagare kalikattākhye kolabrūk、sāhabājñayā | \\ śrīvidyākaramiśreṇa kṛtasūcīsamanvitạ̣ || 2 \| \\ vedarttvaștakalānāthasammite vikramābdake | \\ mudrākṣareṇa vipreṇa bābūrāmeṇa lekhitaḥ || 3 ||
}

1. The Dictionary composed by the Venerable Amara and the Supplement in Three Chapters composed by Purușottama, The Pearl Necklace, Medinī's Homonymyc [Dictionary].

2-3. In the city called Kolkata, at Mr Colebrooke's behest, [this book was] provided with indices by the venerable Vidyākaramiśra; published with movable type by the brahmin Bābūrāma in the year Vikrama calculated as Vedas (4) - Seasons (6) - Eight - Moon (1) (1864).

Is the singular mudrākșarena instead of plural mudrākșarair employed metri causa? This usage occurs also in $\S 2.1 .2$ and $\S 2.1 .5$. The English 'published' renders the Sanskrit term lekhita, as discussed in $\S 4$ below.

\subsubsection{Hemacandra's Abhidhānacintāmaṇi with Anekārthasañgraha}

Bodleian Libraries, Oxford: Sansk. 4.159 (Bābūrāma 1807a).

Published in Kolkata at the Sanskrit Press in 1807. Format: codex.

[Title page]

sānekārthanāmamālātmakaḥ koṣa(!)varaḥ śubhạ̣|

candrapraṇitābhidhānacintāmaṇir maṇiḥ \|| 1 \|

nagare kalikattākhye kolabrūk sāhabājñayā |

śrīvidyākaramiśreṇa kṛtasūcīsamanvitạ̣ || 2 \|

vedarttvaștakalānāthasammite vikramābdake |

mudrākṣareṇa vipreṇa bābūrāmeṇa lekhitạ̣ || 3 \|

1. The Abhidhānacintāmaṇi written by [Hema]candra, a pure jewel, best among dictionaries, together with the homonymic dictionary Anekārtha[sangraha].

2-3. In the city called Kolkata, at Mr Colebrooke's behest, [this book was] provided with indices by the venerable Vidyākaramiśra; published with movable type by the brahmin 
Bābūrāma in the year Vikrama calculated as Vedas (4) - Seasons (6) - Eight - Moon (1) (1864).

In stanza 3, the type for mu was not set and the printed text thus wrongly reads drākșareṇa.

\subsubsection{New Testament}

Bodleian Libraries, Oxford: N.T. Sansk. d.1; 7 E 27; 45 F 18 (Carey 1808). Published in Serampore at the Missionary Press in 1808.

Format: codex.

All three Bodleian copies of this printed volume are different. In N.T. Sansk. d.1, sent to the Bodleian in 1817, the gathering with the signature kha is in Hindi, not Sanskrit. 45 F 18 is an incomplete copy, lacking the title page in English, and is printed on a different type of paper with different dimensions than the other two copies; moreover, a note pasted on the inner side of the front cover states that the copy is bound in the original boards.

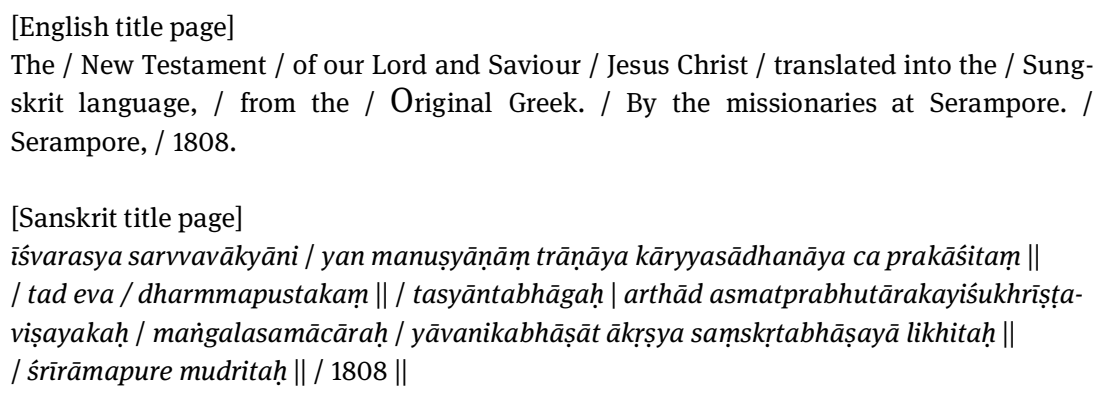
skrit language, / from the / Original Greek. / By the missionaries at Serampore. / Serampore, / 1808.

[Sanskrit title page] iśvarasya sarvvavākyāni / yan manuṣyāṇāṃ trāṇāya kāryyasādhanāya ca prakāśitaṃ \| | tad eva / dharmmapustakaṃ || / tasyāntabhāgaḥ| arthād asmatprabhutārakayiśukhrișțavișayakaḥ / mañgalasamācāraḥ / yāvanikabhāṣāt ākrṣya saṃskṛtabhāṣayā likhitạ̣ || | śrīrāmapure mudritạ̣ || / 1808 ||

Every Sermon of the Lord. This is the Book of the Divine Law which was announced for the protection of the human beings and the betterment of their actions. The New Testament, i.e. The Gospel concerning our Lord and Saviour Jesus Christ. Translated from the Greek language and published in the Sanskrit language. Printed in Serampore. 1808.

Note the reduplication of consonants after repha, an orthographic feature peculiar of manuscripts. English 'Divine Law' renders ad sensum the Sanskrit term dharma. Moreover, the Sanskrit phrase tasyāntabhāgah (lit. 'Its final section') corresponds to 'The New Testament' in the English title page, while 'i.e.' renders Skt. arthād in the sense of 'that is to say, namely'. Finally, 'Gospel' is the rendering of the Sanskrit term mangalasamācāra, which in its turn is a calque from the

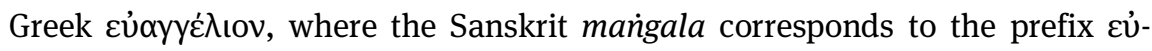


('good'), while samācāra to - $\alpha y y \varepsilon \lambda$ เov ('tale, message'). This rendering is a peculiar choice, since the translators could have easily chosen a rendering more etymologically akin to the Greek original, using the Sanskrit prefix su-for Greek

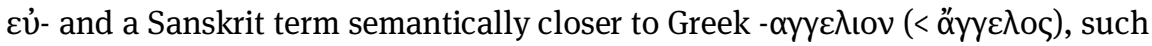
as śāsana, sandeśa or dūta. (In fact, the 1845 Bengali translation of the Gospels is entitled Susamācāra, pointing to a more etymological rendering [Yates et al. 1845]). Interestingly, neither in the PW nor the pw the meaning 'news' is provided for samācāra; however, it is provided both in Wilson's (1832) and Apte's (1965) dictionaries. This fact is particularly relevant in the case of Horace Hayman Wilson's dictionary, for he was active as a scholar roughly in the same period when the Bible translations were made and his Sanskrit-English dictionary was first published in 1819. Unfortunately, in the lemmata of his dictionary Wilson does not provide the textual occurrences of Sanskrit terms. Nevertheless, it is tempting to assume that this meaning for samācāra might derive precisely from these translations.

\subsubsection{Pentateuch}

Bodleian Libraries, Oxford: N.T. Sansk. d.1; 7 E 27; 45 F 18 (Carey 1811). Published in Serampore at the Missionary Press in 1811. Format: codex.

The Bodleian copy consulted lacks the added English title page, which in the Bodleian Libraries' online catalogue (SOLO) reads as follows: 'Pentateuch, translated into the Sungskrit language, from the original Greek [sic]. By the missionaries at Serampore.' (transcribed from the copies kept at Regent's Park College Library: Angus Library, Bib.18 and Baptist Missionary Society collection, Sanskrit 6).

\footnotetext{
[Sanskrit title page] iśvarasya sarvvavākyāni / yanmanuṣyāṇāṃ trāṇāya kāryyasādhanāya ca prakāśitam || | tad eva | ādyantabhāgātmakaṃ dharmmapustakam || / tasyādibhāgaḥ / mośahā prakāśitavyavasthā | yiśaraelarājyavivaraṇa | gitāadipustakāni | ācāryyaị̣ prakāśitavākyāni | / etac catuștayātmakaḥ || / tasyāntargatā mośahā prakāśitavyavasthā / ebaribhāṣāt ākrṣ̂ya saṃskṛtabhāṣayā / likhitā || / śrīrāmapure mudritạ̣ || / 1811 ||
}

Every Sermon of the Lord. This is the Book of the Divine Law which was announced for the protection of the human beings and the betterment of their actions, comprising the Old and New Testament. Its Old Testament: Genesis, Exodus, Leviticus, Numbers; to this Tetrateuch, the Deuteronomy is added. Translated from the Hebrew language and published in the Sanskrit language. Printed in Serampore. 1811. 
The interpretation of the Sanskrit translation of the titles of the five books in the Pentateuch poses several issues. The expression catuștayātmakah ('having a fourfold structure; Tetrateuch') implies that we have to individuate four books between it and the term ādibhāga ('Old Testament'). ${ }^{2}$ However, since one of these books must be represented by the title mośaha prakāsitavyavasthā, its repetition after catusțayātmakah is rather puzzling, since it would mean that the books of Genesis and Deuteronomy were rendered with the same title. Moreover, even considering the fact that the translators were rendering the Hebrew Torah and not the Greek Septuaginta, it is difficult to explain the discrepancy between the Sanskrit translation and the original Hebrew titles of the books. Traditionally, the Hebrew titles of the books in the Pentateuch consist of the first significant words of each book and the beginning of Genesis is surely not 'the Rule announced by Moses' (Skt. mośahā prakāsitavyavasthā). The only Sanskrit rendering which is immediately understandable is yiśaraelarājyavivarana ('Exposition of the People of Israel') for Exodus, but the rationale behind all other Sanskrit titles remains a mystery to me.

\subsubsection{Bhāravi’s Kirātārjunīya with Mallinātha’s Commentary (Gaṇțāpatha)}

Bodleian Libraries, Oxford: 5 Bharavi 2; Sansk. 2.35.

Niedersächsische Staats- und Universitätsbibliothek, Göttingen: Gretil e-library copy <http://resolver.sub.uni-goettingen.de/purl/?gr_elib-98> (Bābūrāma 1814). Published in Khidirapore (Kolkata) at the Sanskrit Press in 1814. Format: codex.

[Title page, all elements centred]

|| kāryanāma || / | kirātārijunīya || / || kavināma || / || bhāravi || / * / || țīkānāma || / | gaṇțāpatha || / [puṣpikā] / || țīkākāranāma || / || mallinātha $\|$ / / *

Title of the poem: Kirātārijunīya. Name of the poet: Bhāravi. Title of the commentary: Ganțāpatha. Name of the commentator: Mallinātha.

[Flyleaf $1^{\mathrm{r}}$, imprint, all elements centred] || atra kāvye sargasaṃkhyā || / așțādaśa $18 \|$ / * / || atra kāvye mūlaślokasaṃkhyā || / ekapañcāśadadhikasahasraṃ 1052 || / * / || atrārjjunasya kāvyanāyakasya pāśupatāsvalābhah phalam. $\|1\|$ / *

2 On the various hypotheses of the existence of an independent Tetrateuch, see the introductory essay by Ska and Dominique (2006, 4-5). 
Number of chapters in this poem: eighteen 18. Number of verses in this poem: onethousand-fifty-two 1052. Resolution [of the story]: Arjuna, the protagonist of the poem, obtains Śiva's weapon.

[Flyleaf $1^{v}$, imprint, all elements centred]

|| śāke șaḍagnisaptendusammite vatsare śubhe || || śāke 1736 || / || candrādrivasubhūmāne vikramādityavatsare || / || saṃvat 1871 || / || bhūyugmadṛștidharaṇisammite yavanābdake || / || san 1221 sāla || / || vedabhūmivasucandramāsana ìsavīpramāna || / || māhajūna-kevā isācchapyogranthaparadhāna || / || san 1814 ìsavī | tāḥ 22 jūna || /

In the Śāka year calculated as Six - Fire (3) - Seven - Moon (1), an auspicious year. In the Sāka year 1736. In the Vikrama year calculated as - Moon (1) - Mountains (7) - Vasu gods (8) - Earth (1). Vikrama year 1871. In the Islamic year calculated as Earth (1) - Pair (2) Eyes (2) - Earth (1). Year 1221 (?).Gregorian year calculated as Vedas (4) - Earth (1) - Vasu gods (8) - Moon (1). Gregorian year 1814. Day 22 June.

[Flyleaf $2^{\mathrm{r}}$, imprint, all elements centred] nagare kalikattākhye śrīmallāțanṛpājñayā |

śrīidyākaramiśreṇa bāburāmeṇa dhīmatā $\|1\|$ sambhūya śodhayitvātha kāvyaṃ țīkāsamanvitam 、| mudrākșareṇa yatnena nyāsitam sudhiyām mude || 2 || vinā pariśramaṃ dhīrāḥ pāṭhayantu pațhantu ca | tadartham an்itañ caitat sațîkan kāvyam uttamam 、 || 3 \| || saṃskṛtayantre khidirapure śrīmadanapālenāinkitam. ||

1-2. In the city called Kolkata, at the order of the governor-general, [this] excellent poem with a commentary was corrected by the venerable Vidyākaramiśra together with Bābūrāma, then sent to be carefully typeset with movable type for the delight of clever persons.

3. Disciplined persons should cause to recite and recite [it] without trouble; this supreme poem with its commentary was printed for this purpose.

Printed by the venerable Madanapāla at the Sanskrit Press in Khidirapore.

The Islamic date 1221 is wrong, since it corresponds to 1806 and not 1814 (=1229 AH).

\subsubsection{Tattvas from Raghunandana Bhațțācārya’s Smrtitattva}

Bodleian Libraries, Oxford: Sansk. 1.9-11 (R. Bhațāāārya [1830s]).

Edited by Bhabānīcaraṇa Bandyopādhyāya (1787-1848) and printed in Bengali script in Kolkata in the 1830s at the Samācāracandrikā Press. Format: pothī. 
[Colophon]

mahāmahopādhyāyavandyaghațīyasmārtta śrīraghunandanabhațțācāryakrtam

ekādaśîtattvam idaṃ śrībhabānīcaraṇabandyopādhyāyena prayatnataḥ saṃśodhanapū-

rvvakaṃ kalikātānagare samācāracandrikāyantreṇa mudrānikitam

The Ekādaśitattva composed by the venerable Raghunandana Bhaț̣ācārya, mahāmahopādhyāya and revered expert on law; this [book] was revised/edited by the venerable Bhabānīcaraṇa Bandyopādhyāya with care and then printed in the city of Kolkata at the Samācāracandrikā Press.

\subsubsection{Bhāgavatapurāna with Śrīdharasvāmin's Bhāgavatabhāvārthadīpikā}

Bodleian Libraries, Oxford: 4.5.3. Bhag. 35 ([Bhāgavatam with Śrīdhara's commentary] 1830).

Edited by Bhabānīcaraṇa Bandyopādhyāya (1787-1848) and printed in Bengali script in Kolkata in Sāka 1752 (1830 CE) at the Samācāracandrikā Press. Format: 2 volumes, pothī.

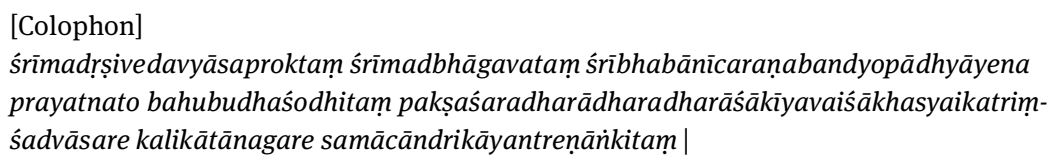

The venerable Bhāgavata[purāna] told by the venerable seer Vedavyāsa, very cleverly edited by the venerable Bhabānīcaraṇa Bandyopādhyāya with care, printed in the city of Kolkata at the Samācāracandrikā Press in the thirty-first day of the month Vaiśākha of the Śāka year Wings (2) - Arrows (5) - Mountains (7) - Earth (1) [i.e. 1752].

\subsubsection{Bhāgavatapurāṇa with Śrīdharasvāmin's Bhāgavatabhāvārthadīpikā}

Bodleian Libraries, Oxford: 4.5.3. Bhag. 4 (Bhāgavatapurāṇa 1860). Printed in Mumbaī by Gaṇapata Kṛ̣̣nājī in 1860. Format: pothī, 13 original tomes bound in 4 volumes.

[Colophon] yathādhvanīnah sthapuțam prayān patham cirāya naijaṃ pratipadyate klišan \| tathā viśuddham pratipadya pustakam budho 'dhigacchaty adhigamyam āspadam || $1 \|$ ato budhaiḥ sūkșmadṛśā vidheyā sā paustakì śodhanikātiyatnāt \| sāhāyyakṛddattavivekadrgvaco manobhirāmākșaramālikāṃcitā || 2 || tat prastutaṃ bhāgavatīyapustakam nirīkṣamāṇau kṛtalakṣaṇān stuvah \| kșetraṃkaropābhidhanāśikasthagoviṃdasadvaidyatanūbhavo 'nyạ̣ || 3 \| revadaṃd̄āpurīvrttilabdhadharmādhikāravān \| 


\author{
harijotramahādevaḥ śodham cakre yathāmati || 4 || \\ krṣnnabhūgaṇapatyākhyamudrāyaṃtrālaye 'male \| \\ tattanūbhavakānhobābhidhena vidușāṃ mude || [5] \\ dvidiggajādrikumite raudrābde śālivāhake \| \\ mārge punye 'grahāyaṇyām mudritạ̣ mudrikākṣaraị̣ || [6]
}

1. Like a traveller walking on a rugged path after long reaches his own [path] experiencing affliction, so a clever man reaches the aspired authority after having studied a correct book.

2. Therefore intelligent men ought to use this slender-looking booklet - a curled little garland pleasing the sight, speech, and mind thanks to the discernment provided by those who helped - in the serious effort of correcting it.

3. Beholding its excellent characteristics, the two of us praise the aforementioned little book on the Bhāgavata: Kșetranikara, another son of the venerable teacher Govinda who resides in Nāśika.

4. Harijotramahādeva, who obtained authority on dharma [i.e law?] etc. through service in the village of Revdanda corrected [this book] to the best of his knowledge.

5-6. His son Kānhoba printed [this book] with movable types in the spotless typographical house Kṛsnabhūganapati for the pleasure of the learned, in the Śaka year Two - Elephants of the Quarters (8) - Mountains (7) - Earth (1) [i.e. 1782], the Jovian year Raudra, in the auspicious month Mārga.

This colophon consists of stanzas in different metres: stanza 1 is in the Vamśastha metre, stanzas 4-6 are in the Anuștubh metre, while stanzas 2 and 3 consists of a peculiar mixture of different metres (verse 2a is in the Upendravajrā, verse $2 \mathrm{~b}$ and $3 \mathrm{~cd}$ in the Indravajrā, $2 \mathrm{c}$ and $3 \mathrm{a}$ in the Indravamśa, $2 \mathrm{~d}$ and $3 \mathrm{~b}$ in the Vaṃśastha).

\title{
2.2 Lithographs
}

\subsubsection{Bhojarāja's Campūrāmāyaṇa with Lakṣmanasūri’s Sixth Chapter}

Bodleian Libraries, Oxford: 5 Bhoja. Campu. 3 (Campūrāmāyaṇa 1848).

Printed in Pune in 1848. Format: pothi.

Bodleian Libraries, Oxford: 5 Bhoja. Campu. 2 and Sansk. 2.25 (Campūrāmāyaṇa 1852).

Printed in Pune in 1852. Format: pothī.

\author{
[Colophon] \\ kāvyālaṃkāraśālāsthadvitīyaguruṇā svayam \| \\ bhojīyacampu(!)șațkāṃ̦ī śodhiteyam yathāmati || 1 \| \\ khasaptasaptemidumite ${ }^{\star}$ śāke punyākhyapattane \| \\ yatnataḥ pāṭhaśālāyām aṃkiteyam śilākṣaraih || 1 ||
}


^khasaptasapteṃdumite] 5 Bhoja. Campu. 3; vedāśvasapteṃdumite Bhoja. Campu. 2 and Sansk. 2.25

1. The second guru in residence of the Society of Poetical Research edited himself Bhoja's Campū[Rāmāyanana] in Six Chapters to the best of his knowledge.

1. Carefully lithographed in the Vedic School (pāțhaśālā) in the city of Pune in the Śāka year calculated as Sky (0) - Seven - Seven - Moon (1) [i.e. 1770] / Vedas (4) - Horses (7) Seven - Moon (1) [i.e. 1774].

These three copies were all printed in the same place, however the manuscript for 5 Bhoja. Campu. 3 was written by a different scribe four years before the manuscript for the other two copies. The colophon of 5 Bhoja. Campu. 3 begins on fol. $74^{\mathrm{r} 2}$, while the colophon of 5 Bhoja. Campu. 2 and Sansk. 2.25 on fol. $73^{\mathrm{v}} 7$.

\subsection{2 Śrīmadbhāgavatacūrṇikā}

Bodleian Libraries, Oxford: 4.5.3. Bhag. 5a (Śrīmadbhāgavatacūrṇikā 1850). Published in Mumbaī by Vițthala Sakhārāma Agnihotrī in 1850. Twelve fascicules, each containing one chapter ( $a d h y \bar{a} y a$ ), bound in one volume; each fascicule foliated separately, colophon in the last fascicule. Format: pothi.

[fol. 9v15]

muṃbākhyapure dvijavaryasakhārāmasūnunā sudhiyā $\|$

svīyaśilāyaṃtro[16]pari viț̣thalanāmnāgnihotriṇa tvarayā $\|1\|$

dvikaturagasaptabhūmitaśāke sādhāraṇābdakāśvayuji \|

graṃtho <'>yaṃ vidvajjanasahāyataḥ pūrṇatāṃ nïtaḥ || 2

In the city of Mumbaī, the learned Vițthala Agnihotrī, son of the eminent Brahmin Sakhārāma, brought quickly to completion this book in the Śāka year calculated as Doublet (2) - Horses (7) - Seven - Earth (1) [i.e. 1772], in the month Āśvin of the Jovian year Sādhāraṇa, thanks to the support of knowledgeable individuals.

\subsubsection{Jaiminī’s Aśvamedhaprākṛta}

Bodleian Libraries, Oxford: (IND) $11 \mathrm{~F} 1$ (Jaiminī Aśvamedha prākṛta 1850)

Probably printed in Mumbaī in the 1850s, unidentified publisher. Format: pothī (various foliations).

[chapter 96, fol. $4^{\mathrm{r}} 12$ ]

|| śake satrāṃśe ekūṇahāttarị̣̄ \|| plavaṃganāmasaṃvatsarīm \| graṃtha chāpilā śịāyaṃtrị̣̄ || viśvavāthasutem gaṇeśem [13] || 1 || yādṛ́śm pustakaṃ dṛșțā tādṛśaṃ 
likhitam mayā || yadi śuddham aśuddham vā mama doṣo na vidyate || 1 || [14] || cha \| $\quad$ || cha \| \|cha\| \|cha\|

Lithographed in the Saka year seventeen sixty-nine, in the Jovian year called Plavañga, by Gaṇeśa, son of Viśvanātha. In the same form as I saw the manuscript, I have written [a copy]; if something is correct or incorrect, it is not my fault.

\subsubsection{Jaiminī’s Aśvamedha}

Bodleian Libraries, Oxford: 4.3.2. 43 (Bāpūsadāśivaśeṭha 1850).

Printed in Mumbaī by Bapu Sadashiv Shet Hegiste in 1850. Format: pothī.

[fol. 125 4 ]

sadāsivivasuto bāpur hegișthety upanāmakaḥ aśvamedhaṃ mohamayyām ujjahāra śilāmaye 1 svīye yaṃtre śucau śukle ravau kāmatithau [5] tathā śāke netrādrimunibhūmite |1772/ sampūurnatām agāt 2 śubhaṃ bhavatu cha cha cha cha

Bapu son of Sadashiv, nicknamed Hegisthe, removed the delusion (?), brought to completion the Aśvamedha in his own lithographic press in the hot month [i.e. Āṣāḍha or Jyeștha], in the bright half, on Sunday, in the lunar day of Kāma, in the Saka year Eyes (2) - Mountains (7) - Sages (7) - Earth (1), i.e. 1772. Let there be bliss!

\subsubsection{Bhāgavadgītā with Śrīdharasvāmin's commentary Subodhinī}

Cambridge University Library 834:1.a.85.54 (Bāpūsadāśivaśețha 1861). Printed in Mumbaī by Bapu Sadashiv Shet Hegiste in 1861. Format: pothì.

[fol. 105 $5^{\mathrm{r}} 12$ ]

samāpto <'>yam graṃthah śrīkrșnārpanam astu [13] hem pustaka bāpusadāśivaśețha

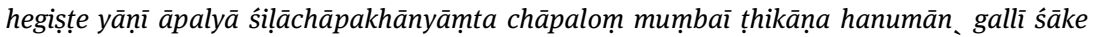
1783 durmanināmasamvatsare

This volume is completed. Let [it] be an offer to the Venerable Kṛșna! This book was printed by Bapu Sadashiv Shet Hegiste [= Bapu, the son of Sadashiv] in his lithographic press, Mumbaī, Hanuman Lane, in the Śāka year 1783, in the Jovian year named Durmati.

\subsubsection{Kamalākarabhațta’s Śūdrakamalākara}

Cambridge University Library 834:1.a.85.44; Bodleian Libraries, Oxford: Sansk. 1.47 (Kamalākarabhațta 1861).

Printed in Mumbaī in 1861. Format: pothī. 
[fol. 94 $4^{\mathrm{r}} 6$ ]

hem pustaka, vedaśāstrasampanna rājamānya gaṇeśabāpūjiśāāstrī mālavaṇakara āṇi rājaśrī kailāsavāsī viṣnubāpūjiśāstrī vāpațayā [7] ubhayatāmnnīm bhāgīteṃ chāpaleṃ ase \| śake 1783 durmatināmasaṃvatsare \| mārgaśīrșe māsikṛṣnapakṣe ravivāsare idam pustakaṃ samāptam. || || [8] trināgasapteṃdumite śake muṃbākhyapațtaṇe || yatnataś ca gaṇeśena aṃkito <'>yaṃ śilākṣaraị̣ || 1 || || cha || cha

This book was published by Ganeshbapuji Shastri Malvankar and Late Vishnubapuji Shastri Bapat. This book was finished in the Śaka year 1783, in the Jovian year named Durmati, in [the month] Mārgaśīișa, in the dark half of the month, on Sunday. In the Śaka year calculated as Three - Serpents (8) - Seven - Moon (1), Ganeśa carefully lithographed this [volume].

\subsubsection{Rāmakiśora Śarmā Bhațțācārya’s Mudrāprakāśa}

Bodleian Libraries, Oxford: 45 F 27 (R. Ś. Bhaț̣ācārya 1867).

Printed in Vārāṇasī at the Siddhavināyaka press in the Ḍhụ̣uhirāja Gaṇeśa temple in Vikrama 1924 / Sāka 1789 [1867 CE]. Format: pothī.

[Title Page]

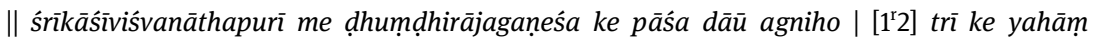

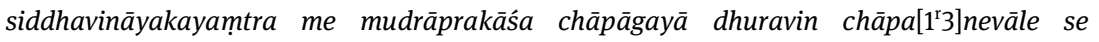
likhāviśeśara upādhyā saṃ. 1893 pha.sū. 10 śukravāsare.

The Mudrāprakāśa was printed at the Siddhavināyaka press at the place of Dau Agnihotrī near the Ḍhuṇ̣̂hirāja Gaṇeśa temple in Vārāṇasī, the city of Śiva, by the printer Dhurvin, [after] it was written by the scribe Viś[v]eśara Upādhyāya in the [Vikrama] year 1923, in the bright half of the month Phalguna, on Friday.

[Colophon, 20v7]

saṃvat 1924 || śāke 1789 || caitrakṛ̦̣na 5 caṃdravāsare || subham bhūyāt || maṇibaṃdhayutau kṛtvā prașrtāmgulikau karau kanișțhāmgușțhayugale | militvāṃtaprasārite jvālinīnāma mudreyaṃ vaišvānarapriyaṃkarī 1 || samāptaś cāsau graṃthạ̣ || śrīr astu śubham

In the Vikrama year 1924; in the Saaka year 1789; in the dark half of the month of Caitra, on Monday. Let there be bliss! If the wrists are joined, the hands with fingers stretched, the couple of little finger and thumb is conjoined and stretched to the end, this is the mudrā named Jvālinī, producing joy for all mankind. And this volume is completed. Let there be prosperity, bliss!

The Bodleian copy belonged to Monier-Williams, as attested by his ex libris pasted on the internal front cover and a note in pencil on fol. $1^{\mathrm{r}}$ ('Most respectfully presented to Professor Monier Williams Esq. by his most obedient Pandit(!) 
Bihárí Chaulie of the Benares College 19/1/76 Benares'). The Wellcome Library copy (shelfmark: Sanskrit litho 112) was printed in the month Pauśa; moreover, according to the bibliographical description on the Wellcome Library catalogue, its title page/imprint is identical to the Bodleian copy only up to the words mudrāprakāśa chāpāgayā, while the text that follows differ considerably: vamsīdhara miśra chāpanevālà māna jisai lenā hoya usai ḍhuṃ̣hirājagaṇeśa ke pāśa dāū agnihotrī ke dukāna para milaigā.

\subsubsection{Yogivaryyavipra Rājendra's Așțāngaśuddhi}

Bodleian Libraries, Oxford: Sansk. 3.151 (Rājendra 1860).

Place and publisher not identified, publication date between 1860 and 1880 . Format: pothī.

[Colophon] vidyodayo nirākuryād avidyātimiraṃ sadā $\|$ sahasrāṃśur ivāseseṣaṃ mudrākiraṇarājibhịh || $1 \|$

1. May the rise of knowledge completely dispel the darkness of ignorance, as if it was the sun with his thousand rays, thanks to the beaming lines (kiraṇarāji) of print (mudrā)!

\section{Terminology}

The glossary lists the terms in Roman alphabetical order; each term is followed by the references to its occurrence in the texts presented in $\S 2$. I have checked the meanings of each term as provided in the following Sanskrit dictionaries (see Abbreviations below):

- Wilson 1832.

- Böhtlingk and von Roth 1855.

- Böhtlingk 1879.

- Monier-Williams 1899.

- Schmidt 1928.

- Apte 1965.

- Mayrhofer 1986.

- Nachtrags-Wörterbuch des Sanskrit.

Wilson's dictionary is particularly important for our purpose insofar it was prepared and published in the same period and cultural environment of the 
typographies in which the earliest Sanskrit books were printed. As a methodological rule, I consider the meanings provided in the PW, the pw, Schmidt, and the NWS as last instances, since they all provide the occurrences of a term (with the only exception of the pw), while Wilson, the MW, and Apte do not. ${ }^{3}$

\subsection{Printing}

\section{ankita}

[2.1.5-7, 2.2.1, 2.2.6] 'Printed'. The past participle passive of the verb ankay(denominative from $a \dot{n} k a$ ) denotes something curved or bent (for instance, a hook or any curved part of the human body), thus including any type of written sign. Occasionally it is used as a synonym of mudrita, however it mostly denotes any type of printed text, regardless of the kind of technology employed. Accordingly, it is often further defined, as in the compound mudrānikita, 'printed typographically', or in the expression amkito 'yam [scil. granthah] śilākșaraih., 'this [book] was lithographed' (lit. 'this [book] was printed by means of lithographic characters').

\section{mudrā (mudrita)}

[2.1.1-6, 2.1.8, 2.2.8] '(Typographic) print'. The term mudrā and its derivatives are the standard terms used in Sanskrit to denote print and print technology in general. As in the case of most Sanskrit terms related to writing, the etymology points to a Persian origin (Mayrhofer 1986, s.v.). ${ }^{4}$ A comprehensive discussion of the various meanings of mudrā related to writing technology is provided by Falk (1993, 299-301). Its primary meaning related to print technology is 'seal' or 'stamp', extending also to any kind of sign or symbol created by means of the seal or stamp itself (in particular, mudrā is closely connected with the sphere of coinage). The shift towards the specific meaning of 'typographic print' is explained in detail in $\S 4$.

\section{mudrākșara (mudrikākșara)}

[2.1.1-2, 2.1.5, 2.1.8] 'Type, movable type'. The compounds mudrākșara and mudrikākșara, lit. 'stamp-character', is used in opposition to śilākșara, 'stone-

3 Since the MW is the most used Sanskrit-English dictionary, and the glossary in this article is Sanskrit-English too, this choice might seem counter-intuitive to non-Indologists; the rationale behind it rests on the considerations Roland Steiner put forward in a recent article (Steiner 2020).

4 On the foreign origin of Sanskrit terms pertaining to writing technology see Falk (2009). 
character', and can thus be safely understood and translated as 'movable type'. See also $§ 4$.

mudrānikita

[2.1.6] See s.v. arkita.

nyāsita

[2.1.5] '(tasked to be) typeset (?)'. In the material examined here, this term occurs only in the imprint of the 1814 edition of Bhāravi's Kirātārjunīya. In this context its meaning is dubious and rests ultimately on the interpretation of other terms occurring in the same imprint. It is a past passive participle from the causative form of the verb ni-as, meaning 'cause to lay or put down', and if our understanding of the other terms is correct, then the most probable meaning of nyāsita must relate to the typesetting process, as explained in $\S 4$.

yantra (mudrāyantra, mudrāyantrālaya, śilāyantra)

[2.1.5, 2.1.6, 2.1.7, 2.1.8, 2.2.2, 2.2.3, 2.2.4, 2.2.7] 'Printing press'. The Sanskrit term yantra denotes any mechanical device, therefore it is often further defined, occurring in expressions such as mudrāyantra, 'typographic press', śilāyantra, 'lithographic press', and other similar compounds.

\section{śilākșara}

[2.2.1, 2.2.6] 'Lithographic character' and, by extension, 'lithography'. See also s.v. ankita.

\subsection{Editing and publishing}

$\bar{a} k r s ̦ y a$

[2.1.3, 2.1.4] 'To translate'. This term occurs only in translations of the Bible and might be considered a calque from the English 'translate' (or even directly from the Latin transferre, where $\bar{a}-=$ trans- and $k r s$ - $^{-}=$ferre). However, since Apte provides the meaning 'to supply a word or words from another rule or sentence' (albeit without listing any occurrence), it could be that ākrṣ- in Sanskrit could already have meant 'to translate'. It is worth noting that any form or derivative of the verb anu-vad (such as the causative gerund anuvādya or the substantive anuvāda) would have been more straightforward Sanskrit renderings of the English "translation", and probably also more intelligible for Bengali (and Hindi) native speakers. 


\section{likhita / lekhita}

[2.1.1-4, 2.2.3, 2.2.7] 'Composed / commissioned for composition'. The verb likhmeans 'to scratch' (Mayrhofer 1986, 3.58, s.v. rikháti) and by extension 'to engrave, inscribe, write, paint'. It occurs in colophons of manuscripts invariably denoting the scribe as opposed to the author of the text. If author and scribe coincide, as in the case of autographs, usually the two aspects of creating the text and writing the manuscript are clearly distinguished in the colophon, with a form of verbs such as $k r$ - or vi-rac-describing the act of composing the text, while likh- the material act of writing the manuscript. ${ }^{5}$ On the other hand, it seems that likh- was occasionally used also with the meaning 'to compose', as explained in detail in $\S 4$.

śudh-

[2.1.5-8, 2.2.1, 2.2.3] 'To correct, emend'. Already in the manuscript tradition derivatives of this verbal root are used as standard terms to denote correcting, emending, and similar activities. In the material examined here the following forms occur: śuddha, viśuddha, śodha, śodhita, śodhanikā, śodhayitvā, samśodhana. The term sodhanikā is a curious hapax which occurs alongside another hapax, paustaki; both terms are simply diminutives, respectively from śodhana and pustaka, and their meaning is clear from the context.

\subsection{Terminology for dates}

isavī

[2.1.5] In the imprint of the 1814 edition of Bhāravi's Kirātārjunīya the date is provided in four different calendars: Sāka, Vikrama, Islamic, and Gregorian. The term used to indicate the Gregorian is Hindi issavi, not attested in Sanskrit dictionaries. It is the adjective derived from Hindi İsava, 'Jesus'.

${ }^{\circ}$ mite / ${ }^{\circ}$ sammite / ${ }^{\circ}$ māne

[2.1.1, 2.1.2, 2.1.5, 2.1.8, 2.2.1, 2.2.4, 2.2.6] 'Calculated; measuring'. The past participle passive of the verbal root $m \bar{a}$ (with or without a preverb) often occurs at the end of compounds expressing the year with chronograms (bhütasainkhyā). They are used in the sense of 'measured, calculated as; measuring ('māne)'. Similar expressions occur rarely in colophons of Sanskrit manuscripts written

5 See for instance Formigatti (forthcoming). 
before the eighteenth or nineteenth century, ${ }^{6}$ but are very common in both typeset and lithographed printed books.

\section{A few preliminary conclusions}

Albeit limited in scope, the material examined above allows us to make a first important observation: in order to understand the correct purport of terms having an apparently well-known meaning, we have to be alert to the cultural context in which they were employed. The most striking example is mudrā, the Sanskrit term for print par excellence. Among other meanings, the PW provides also 'type, wooden type' ('Type, Holztype'), pointing to a passage from the Khadgamālātantra as quoted in the Sabdakalpadruma, in which the term mudrā occurs alongside other terms denoting different types of writing technologies. Moreover, under mudrālipi the PW points to a similar passage from the Vārāhitantra, quoted again in the Śabdakalpadruma. In the latter, the two passages are quoted one after another:

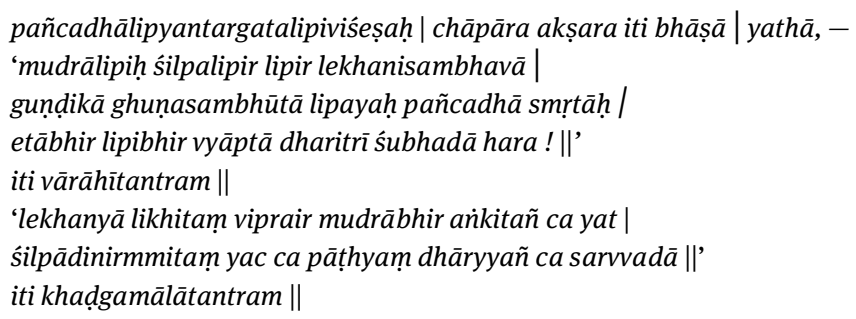

$[M u d r \bar{a}]$ A kind of script included in the fivefold scripts; 'printed character' in vernacular; like [in the following passages]:

'Five kinds of scripts are traditionally recognised: script by means of a seal/stamp, script by means of a stylus, script originating from a reed-pen, script in the sand, script made by woodworms. The prosperous Earth is covered with these scripts, o Siva!'

(Vārāhìtantra)

'What is written by Brahmins with a reed-pen and printed by means of a seal/stamp, as well as formed with a stylus and so on, should always be recited and worn!'

(Khaḍamālātantra)

6 A notable exception is for instance Cambridge University Library MS Add. 2318, a Jaina manuscript of the Śabdānuśāsanalaghuvṛttyavacūri written in 1472 Vikrama, i.e. $1415 \mathrm{CE}$ (<https://cudl.lib.cam.ac.uk/view/MS-ADD-02318/32>). 
The NWS provides two meanings for mudrālipi, 'incised letter; impressed letter' and simply 'a kind of script'. The first meaning refers to the glossary in Murthy's Introduction to Manuscriptology (Murthy 1996), while the second meaning refers to Edgerton's Buddhist Hybrid Sanskrit Dictionary, which provides a reference to the Mahāvastu, where the term occurs in a passage listing a series of scripts (Senart 1882, vol. I, 135). In this list, in many cases the names of the scripts are rather obscure and it is not immediately clear according to which criteria they are grouped (or even if they are meaningfully grouped at all). Mudrālipi occurs between the terms lekhālipi and ukaramadhuradaradacinnahūnāpīrā. As Senart notices, the first part of the latter compound is corrupt, and the French scholar

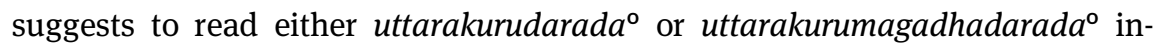
stead, pointing to the parallel well-known list of scripts in the Lalitavistara. ${ }^{7}$ Unfortunately, mudrālipi is not included in the latter list, therefore even accepting Senart's emendation, we cannot establish with certainty with which scripts mudrālipi might be grouped in the Mahāvastu. Senart suggests to translate it as 'l'écriture des sceaux' ('the script of seals'), however noting that mudrālipi seems to denote a particular use or form of a script, like in the case of lekhälipi, which he translates as 'l'écriture épistolaire' or "l'écriture cursive" ('the script of letters', i.e. 'the cursive script'). ${ }^{8}$ I believe we might understand the purport of the rather elusive term mudrālipi if we go back to the passages quoted in the Sabdakalpadruma. As we have seen, Senart understands lekhālipi as a definition of the informal cursive script employed for letters, and consequently under mudrālipi he probably understands a specific style of script used for seals and stamps. However, the passages from the Vārāhittantra and the Khadgamālätantra clearly mention different writing instruments rather than different script styles. Most probably, gundikālipi and ghunalipi refer respectively to the practice of writing ephemeral texts in the sand and to the meaningless forms created by insects when eating into palm leaves and wood. ${ }^{9}$ As to the first three types of scripts

7 'Les noms ukara madhura varada sont sûrement corrompus; il paraît permis de les corriger, d'après l'analogie du Lal. Vist., en uttarakurudarada ou peut-être en uttarakurumagadhadarada' (Senart 1882, vol. I, 483).

8 'Une autre [catégorie] est celle des épithètes qui paraissent désigner des emplois ou des formes particulières de l'écriture lekhālipi "l'écriture épistolaire”, c'est-à-dire "l'écriture cursive”, mudrālipi “l'écriture des sceaux”' (Senart 1882, vol. I, 484).

9 The term ghunalipi in the Vārāhitantra refers to a well-known anonymous Sanskrit proverb, quoted for instance in Yaśodhara's commentary to the Kāmasūtra: yad avijñātaśāstrena kadācit sādhitaṃ bhavet | na caitad bahumantavyaṃ ghuṇotkirṇam ivākṣaram || (Dvivedī 1891, 2); 'If a person ignorant of scientific treatises sometimes accomplishes something, this should not be extolled, for it is like a character perforated by a bookworm [in a manuscript]'. 
mentioned, lekhanilipi and śilpalipi refer to characters created by means of the two most common instruments used to write on different types of palm-leaf, while it is safe to assume that mudrālipi refers to characters stamped on any kind of surface by means of a seal or stamp, not exclusively for reading purposes, but also for ritual or even merely decorative purposes. In the light of these considerations, the meaning 'type, wooden type' provided in the PW is too narrow and, above all, anachronistic for the occurrences quoted. In fact, mudrā could hardly refer to movable types (regardless if made of metal or wood), for even though the Portuguese introduced typography on the Indian subcontinent as early as the sixteenth century, initially this technology was employed almost exclusively by Westerners. The first printing presses run by Indians date to the beginning of the nineteenth century (Ross 1999, 118; Rocher and Rocher 2012, 73-75) and most probably it is only during this period that mudrā first starts to denote specifically typographic print and movable types. This observation is underpinned by the use of mudrākșara in opposition to silākșara to distinguish books printed typographically from lithographed books.

The terms likhita/lekhita represent another case in which a careful consideration of the cultural context is fundamental for the correct understanding of the term itself. Occasionally, in printed books the verb likh-, lit. 'to write', is seemingly used in the sense 'to compose', a meaning not listed in the dictionaries. In the first stanza of the Kāryassikșā by the the thirteenth-century Jaina author Vinayacandrasūri, the verb form likhāmi ('I write') is clearly used as a synonym of vi-rac- or $k r$-. Since this form occurs in a stanza, we must first rule out the possibility that the author chose likh- only due to metrical reasons. Indeed, he could not have used the unmetrical form viracayāmi, but he could have easily used karomi, metrically equivalent to likhāmi. Hence, we can suppose that the author purportedly chose to use likh- in the sense of 'to compose' (Shastri 1964, 1). ${ }^{10}$ The shift towards this meaning is clear in later texts and manuscripts, for instance in the Sikșāpatrī, a sacred text of the Svāminārāyaṇa Sampradāya, consisting of a series of moral precepts composed by Sahajānanda Svāmì, the sampradāya's founder. The Bodleian Libraries hosts a particularly important manuscript of this text, MS. Ind. Inst. Sansk. 72, venerated as a relic

10 natvā śrībhāratīm devīm bappabhațtiguror gira(ā) / kāvyaśikṣām pravakșyāmi nānāsāâstranirīkșaṇāt || 1 || vidvanmānitayā naiva [naiva] kīrti[pralobhanāt] | kin tu bālāvabodhāya śāstrād enām likhāmy aham || 2 || ('Bowing before the Venerable Goddess Bhāratī, at the instance of the teacher Bappa I teach the Instruction about Poetry, based on the examination of various treatises. With respect for the learned and not out of the allurement of fame, but for the instruction of the beginners according to the science [of rhetorics], I write (i.e. compose) this [Instruction about Poetry].') 
by the Svāminārāyaṇa community 'for it is said to have been presented to Sir John Malcolm, the governor of the Bombay Presidency from 1827 to 1830, by Sahajānanda Svāmī, the Svāminārāyaṇa Sampradāya's founder who is also venerated as the iștadeva, or chosen deity' (Chag 2016, 170). MS. Ind. Inst. Sansk. 72 is a composite and multi-text manuscript, containing the Sikșāpatri with the Gujarati commentary $(t \underline{i} k \bar{a})$ by the author's pupil Nityānanda Muni, as well as Dīnanātha's Nārāyaṇamunistotra, Śatānanda's Rādhākṛṣnāṣțaka, and a Gujarati hymn by Muktānanda Muni. Interestingly, in the final rubrics and in one of the two colophons of this manuscript we notice an oscillation between the two meanings in the use of likh-. For the sake of clarity, I provide here only the parts of the final rubrics and of the colophon which are relevant to the present discussion. ${ }^{11}$

First codicological unit, final rubric of the Śikṣāpatrī:

iti śrīsahajānaṃdasvāmilikhitā śikșāpattrī samāptā.

The Śikṣāpattrī, composed (likhita) by the Venerable Sahajānandasvāmi is concluded.

Final rubric of the commentary and colophon:

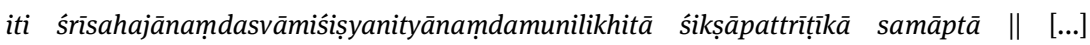
śikṣāpattrịtīkā saṃpūrṇā || lekhakanīkaṃțhānaṃdamuni || śubhaṃ bhavatu \|

The commentary on the Śikṣāpattrī, composed by Nityānanda Muni, disciple of the Venerable Sahajānaṃdasvāmi, is concluded. [...] the commentary on the Sikṣāpattrī is completed. Scribe: Nīkaṇțhānandamuni. Let there be bliss!

Second codicological unit, final rubrics of Dīnanātha's, Śatānanda's, and Muktānandamuni's hymns:

iti dīnānāthabhaț̣aviracītam (!) śrīnārāyaṇamunistotraṃ saṃpūrṇam 、 ||

iti śrīśatānaṃdaviracitaṃ śrīrādhākṛnṣāșțakam saṃpūrṇaṃ\|

iti muktānaṃdamuniviracitaprārthanāṣțakasaṃpūrṇasamāptạ̣ (!) \|

The Hymn to the Venerable Nārāyaṇamuni, composed by Dīnānātha Bhaț̣a, is completed. The Eightfold [Hymn] to the Venerable Rādhā and Kṛṣna, composed by the Venerable Śatānanda, is completed.

The Eightfold Prayer, composed by Muktānanda Muni, is completed and concluded.

11 Full transcriptions are provided in Chag $(2016,206-8)$. 
As expected, the verb form used in the final rubrics to denote the composition of the hymns is viracita. On the other hand, the form likhita is used in the case of the Sikșāpatri and its Gujarati commentary, without distinguishing the role of the authors, Sahajānanda Svāmī and Nityānanda Muni, from that of the scribe, Nikaṇțhānanda Muni. Both codicological units were written in the 1820s, so we have to consider the possibility that the use of likhita as a synonym for krta or viracita is due to the influence of the English language expression 'written, i.e. composed'. On the other hand, the term likhita in the meaning 'composed' is attested also in Bengali. ${ }^{12}$ Notably, the Bengali translation of the four Gospels mentioned in $\S 2.1 .3$ is titled Mathi, Mārka, Lūka, Yohana likhita Susamācāra, 'The Gospels written (i.e. composed) by Matthew, Mark, Luke, John' (Yates et al. 1845). Turning our attention to the books printed in Bengal, a further source of confusion - or maybe of confirmation - comes from the imprint of the 1807 edition of the Nāmalingānuśāsana and other lexica in which, according to C. Vogel, the causative form lekhita (lit. 'caused to be written') means 'typeset'13. However, this translation of lekhita does not take into account Bābūrāma's role in the publication. This term occurs also in the imprint of the 1814 edition of Bhāravi's Kirātāriunīya, where however the term denoting the typesetting process is most probably nyāsita. Moreover, in this book the imprint clearly states that the printer was a certain Madanapāla, therefore Bābūrāma could hardly have been the typesetter. In the task of correctly understanding terms such as lekhita, in my opinion we face two related issues. The first one is that in the period examined, English technical terminology for printing and publishing was translated with Sanskrit terms related to manuscript production. The second issue is that publishing as practised nowadays implies the separation of publishing house and printing press, while Bābūrāma's Sanskrit Press fulfilled both tasks. These two facts render our understanding of lekhita (and other terms) more difficult, since we have to know more about Bābūrāma's role in order to be able to settle for a translation. ${ }^{14}$ As we have seen above, likhita might mean 'written' in the sense of 'composed', therefore I suggest that in this context lekhita does not merely suggests that Bābūrāma had the book typeset, but that he supervised the whole composition - or if we prefer, preparation - of this

12 'likhita a. written [...]; composed; not verbal or oral' (Biswas et al. 1980, s.v.).

13 'Its [i.e. Trikāṇạaseșa's] editio princeps is contained in a collection of four Koṣas (Amarasimha's Nāmalingānuśāsana, Puruṣottamadeva's Trikāṇụaśeșa and Hārāvalī, Medinīkara's Nānārthaśabdakośa) prepared at the instance of H.T. Colebrooke, provided with indices by V. Miśra, and type-set by B. Rāma in Kalikatta, s. 1864 [1807/08]' (Vogel 2015, 54, n. 116).

14 On Bābūrāma and his role in the Sanskrit Press see Formigatti 2016, 103-104, Rocher and Rocher 2012, 41, 74-75, 124, 139, 167, and Kopf 1969, 115, 118, 120, 147. 
specific edition. In other words, he oversaw the whole publication process, his role being rather that of today's publishers. ${ }^{15}$ Accordingly, I would argue that in this context the closest approximation for lekhita in English is 'published'.

Finally, the Sanskrit translations of the Bible represent the most conspicuous case of the influence of the publishers' cultural background on the publication process. Apart from the use of likhita once again in the meaning of 'composed' or 'published', it is maybe the Sanskrit term chosen to render the concept of translation that ironically reveals the most how deeply the missionaries' classical cultural heritage influenced their translation choices, as explained in § 3.2, s.v. ākrșya.

Let us now go back to the questions asked in the introduction and see if we can give an answer to at least some of them, obviously bearing in mind that the limited sample of printed material examined here cannot possibly allow us to provide any conclusive answer. In most cases, it is possible to distinguish the roles of those involved in the printing activity. Interestingly, it seems that roles were more neatly distributed between different individuals in typographic presses than in lithographic presses (cf. $\S \S 2.1 .5$ and 2.1.8). Apparently, in the latter the same person occasionally fulfilled more than one role. For instance, although the colophon of the 1850 edition of the Jaiminyaśvamedhaprākrta is admittedly ambiguous, it seems that the printer Ganeśa might also have written the template manuscript - unless the last stanza was inserted by an anonymous scribe, after all it is a traditional scribal formula found in countless manuscripts (cf. § 2.2.3). Unfortunately, as in the case of manuscripts, the lithographs examined often provide only partial information in their colophons and do not allow to draw any positive conclusion about lithographic book production. Moreover, much like in manuscripts (and unlike in typographically printed books), such information is often provided not in Sanskrit, but in a vernacular language. All this is not surprising, since lithography is a printing technique so close to manuscript culture that some scholars have dubbed it a means for mass manuscript production. On the other hand, the first typographic presses were run by

15 'I searched an earlier version of the book [i.e. Rocher and Rocher 2012], which I was forced drastically to abridge, but I did not find anything on Madanapāla. I took him to be the printer. Bābūrāma was the owner of the press, thus the "publisher". Vidyākaramiśra and some others were pandit commentators and, I guess, [bad] "editors” [...] After Colebrooke came to Calcutta, he used him [i.e. Bābūrāma] to catalog and manage his large and still growing library of copied manuscripts. His management talents must have impressed Colebrooke enough that Colebrooke put him in charge of the printing press I am convinced Colebrooke financed, though there is no document to attest to it.' (Rosane Rocher, personal communication, emails of $11 / 11 / 2020$ and $17 / 01 / 2021)$. 
Westerners and Indian pandits together, printing for a readership consisting mostly of British civil servants, accustomed to Western printed books. More interesting is perhaps to notice that sometime lithographs shift to the title page elements which in manuscripts are usually found in the colophon, as in the 1867 edition of the Mudrāprakāśa (§ 2.2.7). This lithograph is interesting also because of the discrepancy of the printing date between the copy held in the Bodleian Libraries and the copy held in the Wellcome Library. Regrettably, an explanation of the reason behind this discrepancy - as well as several other aspects of Sanskrit print culture - can be explained only with a more thorough study, which goes beyond the scope of this small contribution.

\section{Acknowledgements}

I would like to thank all colleagues and friends who helped me by sharing their knowledge with me: Imre Bangha, Daniela Bevilacqua, Daniele Cuneo, Madhav Deshpande, César Merchan-Hamann, Emma Mathieson, Cristina Pecchia, Rosane Rocher. Needless to say, all remaining blunders are due to the author's nescience.

\section{Abbreviations}

\begin{tabular}{|c|c|}
\hline Apte & Vaman Shivaram Apte, The Practical Sanskrit-English Dictionary, 1965. \\
\hline PW & Otto von Böhtlingk and Rudolf von Roth, Sanskrit-Wörterbuch, 1855. \\
\hline pw & Otto von Böhtlingk, Sanskrit-Wörterbuch in kürzerer Fassung, 1879. \\
\hline Mayrhofer & Manfred Mayrhofer, Etymologisches Wörterbuch des Altindoarischen, 1986. \\
\hline MW & $\begin{array}{l}\text { Monier Monier-Williams, Ernst Leumann and Carl Cappeller. A Sanskrit-English } \\
\text { Dictionary, } 1899 .\end{array}$ \\
\hline NWS & Nachtrags-Wörterbuch des Sanskrit. \\
\hline Schmidt & $\begin{array}{l}\text { Richard Schmidt and Otto von Böhtlingk, Nachträge zum Sanskrit-Wörterbuch } \\
\text { in kürzerer Fassung von Otto Böhtlingk, } 1928 .\end{array}$ \\
\hline Wilson & H. H. Wilson, A Dictionary in Sanskrit and English, 1832. \\
\hline
\end{tabular}




\section{References}

\section{Primary Sources}

Bābūrāma (ed.) (1807a), [Abhidhānacintāmaṇi with Anekārthasanigraha], Calcutta: Bābūrāma. Bābūrāma (ed.) (1807b), Śrīmadamarakṛtakoṣaḥ Purușottamakrtatrikaṇḍaśeṣañ ca Hārāvalyabhidhānam medinīkarasya nānārthaḥ, Calcutta: Bābūrāma.

Bābūrāma (ed.) (1814), Kirātārjjunīya, Khidirapura: Saṃskṛtayantra.

Bāpūsadāśivaśețha (ed.) (1861), Śrīmadbhagavadgītā Śrīdharācāryapraṇītayā Subodhinīvyākhyayā Vibhūṣitā, Bombay: s.n.

[Bhāgavatam with Śrīdhara's commentary] (1830), Calcutta: Samācāracandrikā Press. Bhāgavatapurāṇa (1860), Bombay: Gaṇapata Kṛ̣ṇājī.

Bhaț̣āaārya, Raghunandana (ed.), [1830s], [Tattvas extracted from the Smrtitattva], Calcutta:

Samācāracandrikā Press.

Bhaț̣̂āārya, Rāmakiśora Śarmā (1867), Mudrāprakāśa. Benares: Ḍhuṇ ḥhirāja Gaṇeśa.

Campūrāmāyaṇa (1848), Pune: Pāṭhaśāā.

Campūrāmāyaṇa (1852), Pune: Pāṭhaśāāā.

Carey, William (ed.) (1808), İśvarasya sarvvavākyāni [...] yāvanikabhāṣāta ākṛşya

Samskṇtabhāṣayā likhitah. New Testament of our Lord and Saviour Jesus Christ translated into the Sungskrit language, from the original Greek. By the missionaries at Serampore,

Serampore: [Missionary Press].

Carey, William (ed.) (1811), İśvarasya sarvvavākyāni [...] ebaribhāṣāta ākrșya saṃskrtabhāṣayā likhitā, Serampore: [Missionary Press].

Jaiminī Aśvamedha prākṛta (1850), [Bombay?]: s.n.

Bāpūsadāśivaśețha (ed.) (1850), Jaiminikrttāśvamedhaḥ, Bombay: s.n.

Kamalākarabhațța (1861), Śūdrakamalākara, Bombay: Gaṇeśa Śāstrī Mālavaṇakara va

Kailāsavāsī Viṣṇu Śāstrī Bāpața.

Rājendra, Yogivaryyavipra (1860), Aștāingaśuddhi, India: s.n.

Śrīmadbhāgavatacūrṇikā (1850), Bombay: [Vițțhala Sakhārāma Agnihotrī].

\section{Dictionaries (in chronological order)}

Wilson, H. H. (1832), A Dictionary in Sanskrit and English: Translated, Amended, and Enlarged from an Original Compilation, Prepared by Learned Natives for the College of Fort William, 2nd edn, Calcutta: Printed at the Education Press.

Böhtlingk, Otto von and Rudolf von Roth (1855), Sanskrit-Wörterbuch, St. Petersburg: Buchdrückerei der kaiserlichen Akademie der Wissenschaften.

Böhtlingk, Otto von (1879), Sanskrit-Wörterbuch in kürzerer Fassung, St. Petersburg: Buchdrückerei der kaiserlichen Akademie der Wissenschaften.

Monier-Williams, Monier, Ernst Leumann, and Carl Cappeller (1899), A Sanskrit-English Dictionary: Etymologically and Philologically Arranged with Special Reference to Cognate Indo-European Languages, New Edition, Greatly Enlarged and Improved with the Collaboration of E. Leumann, C. Cappeller and Other Scholars, Oxford: Clarendon Press. 
Schmidt, Richard and Otto von Böhtlingk (1928), Nachträge zum Sanskrit-Wörterbuch in kürzerer Fassung von Otto Böhtlingk, Leipzig: 0. Harrassowitz.

Apte, Vaman Shivaram (1965), The Practical Sanskrit-English Dictionary: Containing Appendices on Sanskrit Prosody and Important Literary \& Geographical Names in the Ancient History of India, 3rd Revised \& Enlarged edition, Delhi: Motilal Banarsidass.

Mayrhofer, Manfred (1986), Etymologisches Wörterbuch des Altindoarischen (Indogermanische Bibliothek. II. Reihe, Wörterbücher), Heidelberg: Winter.

Nachtrags-Wörterbuch des Sanskrit. Ein kumulatives Nachtragswörterbuch zu den Petersburger Wörterbüchern ( $p w$ ) von Otto Böhtlingk und den Nachträgen von Richard Schmidt: <https://nws.uzi.uni-halle.de〉.

\section{Secondary literature}

Biswas, Sailendra, S. C. Sen Gupta, Sudhangshukumar Sengupta and Birendramohan Dasgupta (1980), Samsad English-Bengali Dictionary, Revised \& Enlarged 5th Edition, Calcutta: Sahitya Samsad.

Chag, Avni (2016), 'Manuscript as Relic: The Svāminārāyanạ Śikṣāpattrī Manuscript in the Bodleian Library, Oxford', The Bodleian Library Record, 29 (2): 170-208.

Dvivedī, Durgāprasāda (1891), Kāmasūtram. Vātsyāyanapraṇitaṃ; Yaśodharaviracitayā Jayamañgalākhyayā țīkayā sametam, Bombay: Nirṇayasāgaraḥ.

Falk, Harry (1993), Schrift im alten Indien: ein Forschungsbericht mit Anmerkungen (Script Oralia, 56), Tübingen: Narr.

Falk, Harry (2009), 'Foreign Terms in Sanskrit Pertaining to Writing', in The Idea of Writing: Play and Complexity, Leiden: Brill, 207-17.

Formigatti, Camillo A. (2016), 'A Forgotten Chapter in South Asian Book History? A Bird's Eye View of Sanskrit Print Culture', in Hildegard Diemberger, Franz-Karl Ehrhard, and Peter Kornicki, (eds), Tibetan Printing: Comparison, Continuities, and Change, Leiden: Brill, 72134.

Formigatti, Camillo A. (forthcoming), 'Cambridge University Library MS Add.1698: A Gateway to the Six Languages', in Michael Clarke and Máire Ní Mhaonaigh (eds), Medieval Multilingual Manuscripts: Case Studies from Ireland to Japan (Studies in Manuscript Cultures), Berlin: De Gruyter.

Kopf, David (1969), British Orientalism and the Bengal Renaissance: The Dynamics of Indian Modernization, 1773-1835, Berkeley, CA: University of California Press.

Murthy, R. S. Shivaganesha (1996), Introduction to Manuscriptology, Delhi: Sharada Publishing House.

Rocher, Rosane and Ludo Rocher (2012), The Making of Western Indology: Henry Thomas Colebrooke and the East India Company, Milton Park: Royal Asiatic Society Books / Abingdon: Routledge.

Ross, Fiona G. E. (1999), The Printed Bengali Character and Its Evolution, Richmond: Curzon. Śāstrī, Hariprasāda Gañgāśańkara (1964), Kāvyaśikṣā (Lālabhāī Dalapatabhāī Granthamālā, 3), Amadāvāda: Lālabhāī Dalapatabhāī Bhāratīya Saṃskṛti Vidyāmandira.

Senart, E. (1882), Mahāvastu avadānaṃ. Le Mahâvastu, texte sanscrit publié pour la première fois et accompagné d'introductions et d'un commentaire, Paris: L'Imprimerie nationale. 
Ska, Jean Louis and Pascale Dominique (2006), Introduction to Reading the Pentateuch, Winona Lake, Ind.: Eisenbrauns.

Steiner, Roland (2020), 'Woher hat er das? Zum Charakter des Sanskrit-English Dictionary von Monier-Williams', Zeitschrift der deutschen morgenländischen Gesellschaft, 170 (1): 107118.

Vogel, Claus (2015) Indian Lexicography, revised and enlarged edn (Indologica Marpurgensia, 6), Munich: P. Kirchheim Verlag.

Yates, William and John Wenger (1845), Mathi, Mārka, Lūka, Yohana Likhita Susamācāra, Ebaṃ Preritadera Krì̄āra Bibaraṇa, Yunānīya Bhāshāhaite Bhāshānurīkṛta = The Four Gospels with the Acts of the Apostles, in Bengálí, Calcutta: Printed at the Baptist Mission Press for the Bible Translation Society and the American Foreign Bible Society. 